\title{
Methicillin-Resistant Staphylococcus aureus Strains and Assessment of Its Cytotoxicity Effect on HEK-293 Cells
}

\author{
Mehdi Goudarzi, ${ }^{1,2,}{ }^{*}$ and Hadi Azimi ${ }^{3}$ \\ ${ }^{1}$ Center for the Study of Religion and Health, Shahid Beheshti University of Medical Sciences, Tehran, Iran \\ ${ }^{2}$ Department of Microbiology, School of Medicine, Shahid Beheshti University of Medical Sciences, Tehran, Iran \\ ${ }^{3}$ English Language Teaching Department, School of Medicine, Shahid Beheshti University of Medical Sciences, Tehran, Iran \\ "Corresponding author: Mehdi Goudarzi, Department of Microbiology, School of Medicine, Shahid Beheshti University of Medical Sciences, Tehran, Iran. Tel: +98-123108104, \\ Fax:+98-2122439972, E-mail: gudarzim@yahoo.com
}

Received 2016 November 13; Revised 2016 December 16; Accepted 2016 December 17.

\begin{abstract}
Background: Medicinal plants have been playing important roles in the treatment of different diseases. Peganum harmala is a famous medicinal plant used in the Iranian traditional medicine, due to the antimicrobial compounds found in its seeds and roots. Objectives: The main objective of the present study was to investigate the antibacterial activities of alcoholic extracts of $P$. harmala seeds on MRSA strains and cytotoxicity assessment of ethanolic extract of $P$. harmala seeds on HEK-293 cell line using MTT assay.

Methods: During an 11-month descriptive cross-sectional study, 90 MRSA strains isolated from hospitalized patients in ICU wards were investigated. Micro-broth dilution method was employed to evaluate the antimicrobial effects of the extract on MRSA strains. HEK-293 cells were exposed to different concentrations of ethanolic extract of $P$. harmala and cytotoxicity was evaluated using MTT assay.

Results: The minimum inhibitory concentration of $P$. harmala extract was observed in the range from $3.125 \mathrm{mg} / \mathrm{ml}$ to $25 \mathrm{mg} / \mathrm{mL}$. The most antibacterial activity of the extract was found to be at $12.5 \mathrm{mg} / \mathrm{ml}$ concentration. MRSA strains were inhibited by P. harmala extract at $\mathrm{MIC}_{50}$ and $\mathrm{MIC}_{90}$ of $12.5 \mathrm{mg} / \mathrm{mL}$ and $25 \mathrm{mg} / \mathrm{ml}$, respectively. MTT assay showed that the extract concentrations more than $0.5 \mathrm{mg} / \mathrm{mL}$ were toxic and caused more than 50\% HEK-293 cell death.

Conclusions: The results revealed that the P. harmala extract was very effective against MRSA strains isolated from ICU patients and may be useful to treat some of the infections although further investigation is recommended to assess their toxicity prior to in vivo use.
\end{abstract}

Keywords: Staphylococcus aureus, ICU, MRSA, HEK-293

\section{Background}

Staphylococcus aureus (S. aureus), as a major cause of infection in either hospital or within the community, is responsible for a diverse spectrum of human infections ranging from mild skin infections to urinary tract infections (UTI), osteomyelitis, endocarditis, and lifethreatening diseases such as pneumonia and bacteremia (1). This pathogen has an outstanding capability to acquire resistance, especially against methicillin, making it able to persist in the hospitals and the community. Soon after the introduction of penicillin in the 1960s, Methicillinresistant S. aureus (MRSA) emerged and it has been endemic in hospitals around the world since 1980 s (2). MRSA strains are shown to be able to rapidly develop multidrug resistance (MDR) although a variety of therapeutic measures, including antibiotic therapy, have been introduced. The emergence and spread of MRSA harboring multi-resistance genes have increased academic burden, caused serious therapeutic problems, and worsened controlling infection in hospitals $(3,4)$.

Many in vivo and in vitro studies have shown antibacterial activities of medicinal plants in the past decades. World health organization (WHO) estimated that approximately $80 \%$ of the people in the developing countries trust traditional therapies, and their main medicinal source to treat infectious diseases is plant extracts (5). Oils or extracts of medicinal plants, which have antimicrobial and anti-inflammatory effects, have been recently used to treat many human infectious diseases (6). One of the most famous plants used in popular medicine is Peganum harmala L. (P. harmala), which belongs to Zygophyllaceae 
family and widely grows in steppe areas and sandy soils in Mediterranean region, North Africa, and the Middle East (7). In Iran, this plant is called "Espand", in North Africa "Harmel", and in the United States "African Rue", "Mexican Rue", or "Turkish Rue". P. harmala is a perennial, bushy, wild-growing flowering plant, which has short creeping roots that can grow to $30-100 \mathrm{~cm}$ high (8). Peganum. harmala seeds contain $2 \%$ - $6 \%$ pharmacologically active alkaloids, which are mostly $\beta$-carbolines like harman, harmine, harmaline, and harmalol. Several therapeutic activities including antitumoral, antibacterial, antifungal, anti-parasitic, antinociceptive, anti-inflammation, antiproliferative, vasorelaxant, and antispasmodic activities have been attributed to P. harmala, in literature. Also, the smoke of harmala seeds is traditionally used as disinfectant (9).

\section{Objectives}

The present study was carried out to determine the antibacterial activities of alcoholic extracts of $P$. harmala seeds on MRSA strains. In addition, the cytotoxicity of this extract was evaluated on human embryonic kidney 293 (HEK-293) cell line using the 3-(4,5-dimethylthiazol-2yl)-2,5-diphenyl tetrazolium bromide (MTT) assay.

\section{Methods}

\subsection{Bacterial Strains}

In the present cross-sectional study, 90 MRSA strains were collected from hospitalized patients in ICUs of 5 medical centers in Tehran, Iran, from March 2015 to January 2016. The research was approved by the Ethics Committee of Shahid Beheshti University of Medical Sciences, Tehran, Iran (Code \#6766). The inclusion criterion was existence of MRSA isolated from hospitalized patients in ICUs. The exclusion criterion was $S$. aureus isolated from hospitalized patients, outpatients, community-acquired, and other wards of hospitals. The samples obtained from patients' specimens, including wound ( $n=40 ; 44.4 \%)$, blood ( $\mathrm{n}=30 ; 33.3 \%$ ), pus ( $\mathrm{n}=8 ; 8.9 \%)$, body fluids ( $\mathrm{n}=7 ; 7.8 \%$ ), catheter $(n=3 ; 3.4 \%)$, and urine $(n=2 ; 2.2 \%)$, were transported to the laboratory within 4 hours of collection and were processed according to the standard microbiological procedures, such as colony morphology, Gram staining, growth on mannitol salt agar, and production of catalase, coagulase, and DNase. All the isolates were confirmed using polymerase chain reaction (PCR) for femA and nucA genes (10).

\subsection{MRSA Screening}

Methicillin resistance was detected using a cefoxitin disc (30 $\mu \mathrm{g})$ and an oxacillin disc $(1 \mu \mathrm{g})$ on Mueller Hinton agar plates supplemented by $4 \% \mathrm{NaCl}$ in accordance with the Clinical and Laboratory Standards Institute (CLSI) guideline (11). Isolates with phenotypic resistance to oxacillin were also tested for the presence of mecA gene using PCR.

\subsection{Identifications and Preparation of P. harmala Seeds}

Peganum. harmala was collected from a local farm in the South of Iran in May 2015. Herbarium of the plant was confirmed by research center of medicinal plants. The plant was dried at room temperature and then, the seeds were separated from the other parts and grounded into fine powder. The powder was preserved for the extraction procedure.

\subsection{Preparation of Ethanolic Extract}

The ethanolic extract of the dry powdered seeds was prepared by soaking $10 \mathrm{~g}$ of powdered seeds in $60 \mathrm{~mL}$ of $95 \%$ ethanol for one day (shaking occasionally with a shaker). After one day, suspensions were filtered (Whatman no. 1 filter paper). Then, ethanol was removed by evaporation using a rotary evaporator (6).

\subsection{Minimum Inhibitory Concentration (MIC) Assay}

MIC values were determined for the bacterial strains based on a broth microdilution method. In brief, bacterial suspension was adjusted equivalent to the 0.5 McFarland standard (approximately $1.0 \times 10^{8} \mathrm{CFU} / \mathrm{mL}$ ) in Brain Heart Infusion broth (BHI) medium. This suspension was further diluted $1: 100\left(10^{6} \mathrm{CFU} / \mathrm{mL}\right)$ in the broth medium. MIC values ranged between $1.56 \mathrm{mg} / \mathrm{mL}$ and $50 \mathrm{mg} / \mathrm{mL}$. To each well, $100 \mu \mathrm{L}$ of BHI was added. Then, $100 \mu \mathrm{L}$ of each concentration of extract was added to the wells. The wells with BHI medium (sterility control) and BHI and bacterial suspension (drug-free control) were also used as controls. The plates were wrapped loosely with cling film to ensure that the bacteria did not get dehydrated; they were then examined to determine MIC after incubation at $37^{\circ} \mathrm{C}$ overnight. To estimate MIC of P. harmala seeds, the absorbance of each well was measured at $595 \mathrm{~nm}$. MIC level was defined as the lowest concentration at which no growth was observed.

\subsection{Cell Culture and MTT Assay}

To determine the toxicity of ethanolic extract of $P$. harmala, HEK-293 cell line was used. HEK-293 cell line was cultured in DMEM medium (Dulbecco's modified eagle medium) supplemented with $14 \%$ bicarbonate sodium, 7\% fetal bovine serum, $100 \mathrm{unit} / \mathrm{mL}$ penicillin, $100 \mu \mathrm{g} / \mathrm{mL}$ 
streptomycin sulfate, and $0.25 \mu \mathrm{g} / \mathrm{mL}$ amphotericin B. The cultures were maintained in a $5 \% \mathrm{CO}_{2}$ incubator at $37^{\circ} \mathrm{C}$. The cell count was adjusted to $2 \times 10^{5}$ cells in $1 \mathrm{~mL}$ of fresh medium. To determine viability of HEK-293 cell line, MTT assay was used, which is based on the reduction of a tetrazolium salt by mitochondrial dehydrogenase of viable cells (12).

In brief, cell lines were seeded (8000 cells/well) in a 96well plate and incubated for 24 hours at $37^{\circ} \mathrm{C}$. Different concentrations of $P$. harmala's ethanolic extract (ranging from $1.56 \mathrm{mg} / \mathrm{mL}$ to $50 \mathrm{mg} / \mathrm{mL}$ ) were added to each well and the plate was re-incubated for 48 hours. After incubation, 20 $\mu \mathrm{L}$ MTT $(5 \mathrm{mg} / \mathrm{mL}$ ) was added to each well and the wells were re-incubated for an additional 5 hours. Then, cell culture media and MTT solution were removed and formazan crystals, formed in the last incubation step, were dissolved in $200 \mu \mathrm{L}$ of dimethylsulfoxide. Absorbance was read at wavelength of $570 \mathrm{~nm}$ to calculate the percentage of viable cells using ELISA plate reader $(12,13)$.

\section{Results}

In the present study, all the phenotypically MRSA isolates were found to carry mecA gene, too. The mean age of patients was 41 years (median 40.8 years, ranging from 5 months to 65 years). Wound (44.4\%) and blood (33.3\%) samples were the most prevalent samples in the present study. The level of MIC of seed extract of $P$. harmala was observed in a range from $1.56 \mathrm{mg} / \mathrm{ml}$ to $50 \mathrm{mg} / \mathrm{mL}$. The results of antibacterial activities of $P$. harmala ethanolic extract showed that the growth of 22 MRSA isolates (24.4\%) was inhibited at $25 \mathrm{mg} / \mathrm{mL}, 45$ isolates (50\%) at $12.5 \mathrm{mg} / \mathrm{ml}, 18$ isolates (20\%) at $6.26 \mathrm{mg} / \mathrm{mL}$, and 15 isolates (5.6\%) at $3.125 \mathrm{mg} / \mathrm{mL}$ concentration of the extract. The results showed that $12.5 \mathrm{mg} / \mathrm{mL}$ concentration of the extract had the most antibacterial activity on MRSA strains. All the isolates were inhibited by the P. harmala extract at $\mathrm{MIC}_{50}$ and $\mathrm{MIC}_{90}$ of $12.5 \mathrm{mg} / \mathrm{mL}$ and 25 $\mathrm{mg} / \mathrm{mL}$, respectively.

HEK 293 cell lines were exposed to 12 concentrations of P. harmala extract (0.025, 0.05, 0.01, 0.25, 0.5, 1, 2.5, 5, 10, 25, 50 , and $100 \mathrm{mg} / \mathrm{ml})$. The results of the MTT assay showed that concentrations more than $0.5 \mathrm{mg} / \mathrm{mL}$ of the extract caused cell death over $50 \%$.

\section{Discussion}

The widespread emergence of drug resistance among MRSA strains is becoming a great challenge for public health. This problem leads to the restriction of therapeutic options and exacerbation of disease in hospitalized patients (1). Medicinal plants, as potential sources of natural pharmaceutical products, are playing an important role in the treatment of different diseases (6). Thanks to their fewer side effects, easy access, rational price, and no bacterial resistance, medicinal plants are suitable alternatives for chemical antimicrobial agents (14).

Several studies confirmed antimicrobial properties of P. harmala against different microorganisms $(7,15,16)$. The present study showed a good antibacterial activity for $P$. harmala seeds extract in different concentrations against MRSA clinical strains, which is in agreement with the results of other studies from Iran by Mazandarani et al (17) and Mohsenipour et al (18). The antibacterial activity of $P$. harmala observed in the present study may be due to the existence of high quantity of polyphenols, known to possess efficient antibacterial activity.

In the present study, the MIC of P. harmala extract ranged from 3.125 to $25 \mathrm{mg} / \mathrm{mL}$ against the MRSA strains. Our findings indicated that $12.5 \mathrm{mg} / \mathrm{mL}$ concentration of the extract had the most antibacterial activity against MRSA strains. The value is lower than the earlier value reported by Amel et al. who showed that the concentration of $100 \mathrm{mg} / \mathrm{ml}$ of $P$. harmala seeds extract inhibits the growth of Staphylococcus aureus and Staphylococcus saprophyticus, Escherichia coli, Klebsiella pneumoniae, Pseudomonas aeruginosa, Proteus mirabilis, and Serratia spp.. They also showed a higher antibacterial activity for the seed extract against gram-positive strains, especially $S$. aureus, compared to gram negative tested strains (19). In a study conducted by Darabpour et al., it was reported that the alcoholic extract of $P$. harmala at $50-400 \mathrm{mg} / \mathrm{mL}$ concentrations had inhibitory effects on gram-positive germs, like Bacillus cereus, S. epidermidis, Streptococcus pyogenes, S. aureus, as well as gram-negative germs, like Salmonella typhi, Escherichia coli, Pseudomonas aeroginosa, and Klebsiella pneumonia (20).

Scientific evidence has proven that ethanolic extract of $P$. harmala seeds has strong antibacterial effects on MRSA strains (21). In the study by Hassan Ali et al. in 2011, which was carried out to evaluate the effectiveness of some medicinal plant extracts against clinical isolates, $P$. harmala was shown to be effective on S. aureus, Acinetobacter calcoaceticus, and Candida albicans (22).

However, there are contradictory results about inhibitory effects of various extracts of Peganum harmala. Edziri et al conducted a study to compare the antibacterial, antiviral, and antioxidant activities of various extracts of P. harmala. They showed that chloroform extract had the best antibacterial activity and methanol extract had the best antiviral activity. The chloroform extract may be a significant form of antibacterial compounds against gram-positive bacteria (23). Investigation of P. harmala biological activities in Hayat study clearly demonstrated that 
chloroformic, ethyl acetate, butanolic, and methanolic extracts of $P$. harmala leaves had satisfactory antifungal activities. The chloroformic and methanolic extracts represented a more significant antibacterial activity on grampositive bacteria than gram negative bacteria (24). Also, the results of a study by Moghadam et al. showed that ethanolic P. harmala extract had a high antibacterial activity against MRSA (25). In another study, Mohsenipour et al. showed that the inhibitory effect of ethanolic extracts was more than that of methanolic extract. They also suggested the best inhibitory effect for ethanolic extract of $P$. harmala against $S$. aureus and the lowest inhibitory effect for methanolic extract against S. pneumoniae and K. pneumonia (18). Moreover, in another study, it was demonstrated that the antibacterial and antifungal activities of the acetone extract were more effective than those of the ethanol and aqueous extracts (26). The difference in the reported antimicrobial effects of different extracts of $P$. harmala may be due to the different solubility of various compounds found in P. harmala, particularly when some solvents with specific antifungal or antimicrobial activities are used.

Several studies confirmed that the extracts from seeds and roots of $P$. harmala have more inhibitory effects compared to the extracts from other parts of P. harmala (18). Based on literature, the constituents of roots and seeds are distinct from each other. Amel et al. believed that the seed is more active than the root. They also showed that the concentration of $100 \mathrm{mg} / \mathrm{ml}$ of crude extract of seeds inhibits the growth of all bacterial strains studied, while the same concentration of the crude extract of roots inhibited the growth of $85.7 \%$ of bacterial strains tested (19).

Although this plant has numerous therapeutic properties, it has a great cytotoxicity, as well. When systemically used in high concentrations on animals, P. harmala caused several severe side-effects, including cardiovascular, nervous, hepatic, and gastrointestinal complications. The toxicity of this herb is known to be related to its inhibitory effect on Monoamine Oxidase, and the ability to intercalate into DNA causing frame shift mutation (27). Previous studies have demonstrated cytotoxicity effects of ethanolic extract of $P$. harmala against tumor cells and other cell lines, such as human embryonic skin fibroblast, epithelial carcinoma of uterus cervix, and oral epithelial carcinoma by MTT assay (28). In contrast to other reports which emphasized the antibacterial properties of $P$. harmala in high concentrations, the result of MTT assay in the present study indicated that up to $50 \%$ of cultured HEK 293 cell lines could survive only in concentrations less than $0.5 \mathrm{mg} / \mathrm{mL}$ of this extract $(20,29,30)$. Although high concentrations of $P$. harmala extract have more inhibitory effects on different bacteria especially gram-positive bacteria, the cytotoxic effect of $P$. harmala extract should be considered, as well.
Considering the antibacterial activity of the seed extract of $P$. harmala against MRSA clinical isolates, it can be concluded that this extract could be exploited as an affordable and available source of therapeutic agents as well as an alternative approach to resistance management. Hence, it can be suggested for the treatment of MRSA infections although it is recommended that more studies be carried out to elucidate the precise bioactive natural compounds that lead to cytotoxicity against HEK 293 cell line.

\section{Acknowledgments}

The present study was financially supported by the grant (No. 40222) received from the Center for the Study of Religion and Health, Shahid Beheshti University of Medical Sciences, Tehran, Iran. We would also like to thank the individuals and organizations who participated in the current investigation.

\section{Footnotes}

Financial Disclosure: There was no financial disclosure. Funding/Support: The present study was financially supported by the grant (No. 40222) received from the Center for the Study of Religion and Health, Shahid Beheshti University of Medical Sciences, Tehran, Iran.

\section{References}

1. Goudarzi M, Goudarzi H, Sa Figueiredo AM, Udo EE, Fazeli M, Asadzadeh M, et al. Molecular Characterization of Methicillin Resistant Staphylococcus aureus Strains Isolated from Intensive Care Units in Iran: ST22-SCCmec IV/t790 Emerges as the Major Clone. PLoS One. 2016;11(5):e0155529. doi: 10.1371/journal.pone.0155529. [PubMed: 27171373].

2. Rolinson G. "Celbenin"-resistant staphylococci. British Med J. 1961;1(5219):125.

3. Goudarzi M, Fazeli M, Goudarzi H, Azad M, Seyedjavadi SS. Spa Typing of Staphylococcus aureus Strains Isolated From Clinical Specimens of Patients With Nosocomial Infections in Tehran, Iran. Jundishapur J Microbiol. 2016;9(7):e35685. doi: 10.5812/jjm.35685. [PubMed: 27679706].

4. Goudarzi M, Seyedjavadi SS, Azad M, Goudarzi H, Azimi H. Distribution of spa types, integrons and associated gene cassettes in staphylococcus aureus strains isolated from intensive care units of Hospitals in Tehran, Iran. Arch Clini Infect Dis. 2016;11(4):38813.

5. Folashade O, Omoregie H, Ochogu P. Standardization of herbal medicines-A review. Int J Biodiv Conserv. 2012;4(3):101-12.

6. Goudarzi M, Fazeli M, Azad M, Seyedjavadi SS, Mousavi R. Aloe vera Gel: Effective Therapeutic Agent against MultidrugResistant Pseudomonas aeruginosa Isolates Recovered from Burn Wound Infections. Chemother Res Pract. 2015;2015:639806. doi: 10.1155/2015/639806. [PubMed: 26266047].

7. Nenaah G. Antibacterial and antifungal activities of (beta)-carboline alkaloids of Peganum harmala (L) seeds and their combination effects. Fitoterapia. 2010;81(7):779-82. doi: 10.1016/j.fitote.2010.04.004. [PubMed: 20398742]. 
8. Fadhil S, Reza MH, Rouhollah G, Reza VRM. Spectrophotometric determination of total alkaloids in Peganum harmala L. using Bromocresol green. Res J Phytochem. 2007;1(2):79-82.

9. Mansour M, Soudabe N. The effect of Peganum harmala and Teucrium polium alcoholic extracts on growth of Escherichia coli O157. Jundishapur J Microbiol. 2012;5(3):511-5.

10. Eftekhar F, Rezaee R, Azad M, Azimi H, Goudarzi H, Goudarzi M. Distribution of adhesion and toxin genes in staphylococcus aureus strains recovered from hospitalized patients admitted to the ICU.Arch Ped Infect Dis. 2016.

11. Shin JH, Kim SH, Jeong HS, Oh SH, Kim HR, Lee JN, et al. Identification of coagulase-negative staphylococci isolated from continuous ambulatory peritoneal dialysis fluid using $16 \mathrm{~S}$ ribosomal RNA, tuf, and SodA gene sequencing. Perit Dial Int. 2011;31(3):340-6. doi: 10.3747/pdi.2010.00073. [PubMed: 21454395].

12. Motamedifar M, Khosropanah H, Dabiri S. Antimicrobial Activity of Peganum Harmala L. on Streptococcus mutans Compared to 0.2\% Chlorhexidine.J Dent (Shiraz). 2016;17(3):213-8. [PubMed: 27602397].

13. Mirzaie M, Nosratabadi SJ, Derakhshanfar A, Sharif I. Antileishmania activity of Peganum harmala extract on the in vitro growth of Leishmania major promastigotes in comparison to a trivalent antimony drug. Veterinarski Arhiv. 2007;77(4):365.

14. Mahmoudian M, Jalipour H, Dardashti PS. Toxicity of Peganum harmala: review and a case report. Iranian J Pharmacol Ther. 2002;1(1):1-4

15. Saeidi S, Amini Boroujeni N, Ahmadi H, Hassanshahian M. Antibacterial Activity of Some Plant Extracts Against Extended- Spectrum BetaLactamase Producing Escherichia coli Isolates.JundishapurJ Microbiol. 2015;8(2):e15434. doi: 10.5812/jjm.15434. [PubMed: 25793093].

16. Seyed Hassan Tehrani S, Hashemi Sheikh Shabani S, Tahmasebi Enferadi S, Rabiei Z. Growth inhibitory impact of peganum harmala 1. On two breast cancer cell lines. Iran J Biotech. 2014;12(1):8-14.

17. Mazandarani M, Ghaemi E, Ghaffari F. Antibacterial survey of differ ent extracts of Peganum harmala L. different parts in North east of Golestan province (Inche Borun). 2009 ;4(3):27-38.

18. Mohsenipour Z, Hassanshahian M. Antibacterial activity of Espand (Peganum harmala) alcoholic extracts against six pathogenic bacteria in planktonic and biofilm forms. 2016 ;4(16):109-20.

19. Benbott A, Yahyia A, Belaidi A. Assessment of the antibacterial activity of crude alkaloids extracted from seeds and roots of the plant Peganum harmala. L. J Nat Pro Plant Res. 2012;2(5):568-73.
20. Darabpour E, Motamedi H, Poshtkouhian Bavi A, Nejad S, Mansour S. Antibacterial activity of different parts of Peganum harmala L. growing in Iran against multi-drug resistant bacteria. 2011 ;10:252-63.

21. Moghadam MS, Maleki S, Darabpour E, Motamedi H, Seyyed Nejad SM. Antibacterial activity of eight Iranian plant extracts against methicillin and cefixime restistant Staphylococcous aureus strains. Asian Pacific J Tropical Med. 2010;3(4):262-5. doi: 10.1016/s19957645(10)60063-6.

22. Ali NH, Faizi S, Kazmi SU. Antibacterial activity in spices and local medicinal plants against clinical isolates of Karachi, Pakistan. Pharm Biol. 2011;49(8):833-9. doi: 10.3109/13880209.2010.551136. [PubMed: 21501041]

23. Edziri H, Mastouri M, Mahjoub M, Patrich G, Matieu M, Ammar S. Antibacterial, antiviral and antioxidant activities of aerial part extracts of Peganum harmala L. grown in Tunisia. Toxicol Environ Chem. 2010;92(7):1283-92.

24. Hayet E, Maha M, Mata M, Mighri Z, Laurent G, Mahjoub A. Biological activities of Peganum harmala leaves. Afr J Biotechnol. 2010;9(48):8192-8.

25. Moghadam MS, Maleki S, Darabpour E, Motamedi H, Nejad SMS. Antibacterial activity of eight Iranian plant extracts against methicillin and cefixime restistant Staphylococcous aureus strains. Asian Pac J Trop Med. 2010;3(4):262-5.

26. Valadbeigi T, Moradi H. An investigation of antibacterial effect of methanol and acetone extracts in some lichens in Ilam. 2013 ;2(5):4350 .

27. Arshad N, Neubauer C, Hasnain S, Hess M. Peganum harmala can minimize Escherichia coli infection in poultry, but long-term feeding may induce side effects. Poult Sci. 2008;87(2):240-9. doi: 10.3382/ps.200700341. [PubMed: 18212366].

28. Sobhani AM, Ebrahimi SA, Mahmoudian M. An in vitro evaluation of human DNA topoisomerase I inhibition by Peganum harmala L. seeds extract and its beta-carboline alkaloids. J Pharm Pharm Sci. 2002;5(1):19-23. [PubMed: 12042115].

29. Hasan JM. The antimicrobial and synergistic effect of antibiotics and alcoholic extract of peganum harmala l. seeds on klebsiella pneumoniae isolated from different clinical specimens. $2014 ; 5(6)$ :535-41.

30. Al-Izzy MY. Antimicrobial effects of aqueous and alcoholic extract of Peganum Harmala L. seeds on two types of salivary isolated microorganisms in Al-Ramadi city. Med Sci. 2010;17(4). 